ORIGINAL ARTICLE / ARTIGO ORIGINAL

Psychosocial hearing disadvantage and associated factors among construction workers in Mato Grosso, Brazil

\title{
Desvantagem auditiva psicossocial e fatores associados em trabalhadores do setor da construção em Mato Grosso, Brasil
}

\author{
Andréia Cristina Munzlinger dos Santos ${ }^{1,1}$, Ageo Mário Cândido da Silva',,I!, \\ Gabriela Coelho Pereira de Luccia", Clóvis Botelho', Delma Regina Della Riva'
}

\begin{abstract}
Objective: To estimate the prevalence and to analyze the factors associated with self-reported hearing handicap by construction workers in the state of Mato Grosso, Brazil. Methods: A cross-sectional study was conducted with 866 construction and heavy construction workers. Participants responded to an epidemiological survey subdivided in: identification data, sociodemographic data; lifestyle; work environment characteristics; occupational exposure factors; hearing protection measures; and hearing handicap inventory to quantify the psychosocial consequences of work-related hearing loss. Results: The prevalence of hearing impairment among workers in the construction sector was $14.43 \%(n=125)$. There were 311 emotional and social complaints related to hearing problems. Hearing handicap was associated with: 60 or over age group $(\mathrm{PR}=1.94,95 \% \mathrm{CI} 1.01-3.71)$; alcohol consumption $(\mathrm{PR}=1.94,95 \% \mathrm{CI} 1.38-2.73)$; direct exposure to noise $(\mathrm{PR}=1.75 ; 95 \% \mathrm{CI} 1.03-2.97)$; exposure to dust $(\mathrm{PR}=1.59,95 \% \mathrm{CI} 1.13-2.24)$; non-use of earplugs $(\mathrm{PR}=$ $1.39,95 \% \mathrm{CI} 1.00-1.93)$; and non-use of neck flap cap ( $\mathrm{PR}=1.52,95 \% \mathrm{CI} 1.09-2.13)$. Conclusion: We observed a high prevalence of hearing impairment among workers in the construction sector associated with: individuals aged 60 years or older; alcoholism; exposure to noise and dust; non-use of earplugs; and non-use of neck flap cap. Therefore, it is necessary to implement policies aimed at preserving the hearing health of construction and heavy construction workers.
\end{abstract}

Keywords: Hearing loss; Psychosocial impact; Quality of life; Occupational health; Occupational exposure; Construction industry.

Institute of Collective Health, Universidade Federal de Mato Grosso - Cuiabá (MT), Brazil.

"Centro Universitário de Várzea Grande - Várzea Grande (MT), Brazil.

"'Secretary of Health of the State of Mato Grosso - Cuiabá (MT), Brazil.

Corresponding author: Andréia Cristina Munzlinger dos Santos. Rua Trinta e Três, Quadra 81, Casa 15, Santa Cruz II, CEP: 78077-015, Cuiabá, MT, Brasil. E-mail: fga.andreiacristina@gmail.com

Conflict of interests: nothing to declare - Financial support: Brazilian Public Ministry of Labor - Process nº 000003/2013.

501

REV BRAS EPIDEMIOL JUL-SET 2017; 20(3): 501-513 
RESUMO: Objetivo: Estimar a prevalência e analisar os fatores associados ao handicap auditivo autorreferido por trabalhadores do setor da construção do estado de Mato Grosso, Brasil. Métodos: Foi realizado estudo transversal com 866 trabalhadores da construção civil e pesada. Os trabalhadores responderam a um inquérito epidemiológico subdividido em: dados de identificação; dados sociodemográficos; estilo de vida; características do ambiente de trabalho; fatores de exposição ocupacional; medidas de proteção auditiva; e questionário de handicap auditivo para quantificar as consequências psicossociais da perda auditiva relacionada ao trabalho. Resultados: A prevalência do handicap auditivo entre os trabalhadores do setor da construção foi de $14,43 \%(n=125)$. Foram referidas 311 queixas emocionais e sociais em função dos problemas de audição. O handicap auditivo foi associado com: faixa etária de 60 anos ou mais (RP = 1,94; IC95\% 1,01 - 3,71); etilismo (RP = 1,94; IC95\% 1,38 - 2,73); exposição direta a ruídos ( $\mathrm{RP}=1,75$; IC95\% 1,03 - 2,97); exposição à poeira (RP = 1,59; IC95\% 1,13 - 2,24); não uso de abafador do tipo inserção ( $R P=1,39$; IC95\% 1,00 - 1,93); e não uso de boné do tipo árabe ( RP = 1,52; IC95\% 1,09 - 2,13). Conclusão: Os trabalhadores do setor da construção autorreferiram alta presença de handicap auditivo, sendo associada a: possuir 60 anos ou mais; etilismo; exposição a ruídos e poeira; não uso de abafador do tipo inserção; e não uso de boné do tipo árabe. Portanto, faz-se necessária a implementação de políticas que visem à conservação da saúde auditiva dos trabalhadores da construção civil e pesada.

Palavras-chave: Perda auditiva. Impacto psicossocial. Qualidade de vida. Saúde do trabalhador. Exposição ocupacional. Indústria da construção.

\section{INTRODUCTION}

Construction workers are constantly exposed to high sound pressure levels due to noise emitted by motor graders, wheel loaders, track tractors and other machines. Workers are also exposed to solvents and paints, as well as to certain types of vibration that can damage the auditory system ${ }^{1}$.

Studies show a high prevalence of hearing loss among workers of the construction sector, which ranges from $13-70 \%$ and is higher in professionals with longer exposure times. ${ }^{2,3}$ In Brazil, more than 19 thousand work accidents resulted from hearing problems among construction workers were recorded between 2002 and $2012^{4}$.

Occupational hearing loss has been an important public health problem since it can affect the development of interpersonal communication, language, speech and social interaction, which may impair learning and, consequently, the professional development of the affected population ${ }^{5}$.

In order to quantify the psychosocial consequences of hearing loss, the World Health Organization (WHO) recommends the assessment of the auditory handicap ${ }^{6}$, which corresponds to the emotional and social disadvantages resulting from auditory sensory deprivation $^{7}$. Thus, individuals detected with auditory handicap can present with serious psychosocial losses, leading to isolation, stress, difficulties in family relationships, anxiety, decreased self-esteem and depression ${ }^{8}$. 
Assessment of the auditory handicap differs from the traditional methods of hearing evaluation, as it is performed through self-referenced questionnaires that aim to understand the psychosocial disadvantages associated with hearing loss. Therefore, the questionnaire is an important tool for monitoring the workers' quality of life $\mathrm{f}^{6,7}$. Different from the traditional methods of auditory evaluation, this tool has a low cost since it does not require specialized equipment. For this reason, it can be applied in large scale in occupational hearing screening or even in clinical routine ${ }^{7,8}$.

In the present study, the assessment of the auditory handicap was useful to provide clues about factors that include the prevalence of the consequences of hearing loss among workers in the construction sector, areas and subgroups of populations at risk and subjective dimension of hearing loss that are not revealed by conventional tests. Thus, our objective was to estimate the prevalence and to analyze the factors associated with self-reported hearing handicap by construction workers in the state of Mato Grosso.

\section{METHODS}

We performed a quantitative, observational, cross-sectional study. The interviews were conducted at construction sites in the state of Mato Grosso between September and November 2014, according to prior scheduling with construction workers who were union members.

Inclusion criteria included workers who were fully employed in the construction sector of Mato Grosso, both men and women, aged 18 years and over. Workers on leave or those who did not speak Brazilian Portuguese were excluded.

In order to determine the sample size for finite populations ${ }^{9}$, we considered a population of 20 thousand workers in the construction and heavy construction industry of Mato Grosso in 2014. We considered a significance level of 5\% (corresponding to a $95 \%$ confidence interval, $z[\alpha] / 2=1.96$ ), a tolerable sampling error of $5 \%$, an estimated hearing loss prevalence of $50 \%$ and a design effect of $2 \%$ for group surveys, resulting in a required sample of 754 participants. This first estimate of sample size was increased by $10 \%$ in order to explore associations between health perception and independent variables, making up a minimum sample of 829 workers. In addition, the sample was increased by a further $5 \%$ in order to compensate for possible losses and refusals as the survey included other variables with lower outcomes. In this way, the final number of questionnaires considered for the data collection was 866

For the data collection, we applied a semi-structured epidemiological survey with openand closed-ended questions subdivided into: identification data; sociodemographic data; lifestyle information; work environment characteristics; occupational exposure factors; hearing protection measures; and Hearing Handicap Inventory for the Elderly (HHIE-S $)^{10}$ with a cross-cultural adaptation to Portuguese by Wieselberg ${ }^{11}$ and validation by Carvalho e Iório ${ }^{12}$. This questionnaire is a 10 -item Likert scale (no $=0$; sometimes $=2$; yes $=4$ ) with scores ranging from $0-40$. The items were designed to detect emotional and social problems 
associated with hearing loss. In the present study, to determine the presence of auditory handicap, cut-off point was set as two points or more. Data were entered in the Epi-Info software version 3.5.4 with double independent typing. After verification and control of errors and inconsistencies, data analysis was performed in STATA software version 13.0.

We used absolute and relative frequencies for the analysis of the prevalence of auditory handicap and psychosocial disadvantages. The Mantel-Haenszel chi-square test $\left(\chi_{\mathrm{MH}}^{2}\right)$ was used to examine the association effect between dependent (auditory handicap) and independent variables, with a $95 \%$ confidence interval $(95 \% \mathrm{CI})$. We used Poisson regression for the multivariate analysis, including all variables with $\mathrm{p}$ value less than 0.20 . For the final analysis, we considered only the variables with $\mathrm{p}$ value less than 0.05 .

All participants signed the Informed Consent Form (ICF) and the project was approved by the Research Ethics Committee of the Júlio Müller University Hospital, Mato Grosso, in accordance with Resolution 466/12 of the Brazilian National Health Council.

\section{RESULTS}

We interviewed 866 construction workers and observed a predominance of males $(90.30 \%)$ with a mean age of 34 years $(S D= \pm 11.99$ years), minimum age of 18 years and maximum age of 72 years.

Table 1 shows that the prevalence of self-reported hearing handicap was $14.43 \%(n=125)$. Workers reported 311 psychosocial complaints related to occupational hearing problems. As for the emotional aspect, the most prevalent complaints included feeling embarrassed among strangers $(49.60 \%)$, feeling frustrated or dissatisfied when among family $(37.60 \%)$ and feeling harmed by the auditory problem (24\%). In relation to the social aspect, the most prevalent complaints were difficulty hearing someone whispering $(50.40 \%)$, attending church less $(18.40 \%)$ and difficulty when listening to TV or radio $(18.40 \%)$.

Table 2 shows the associations between the auditory handicap and the sociodemographic and lifestyle variables. After establishing the age group $17-29$ years as a comparison category, we found higher prevalences of high auditory handicap only in the age group 60 years or older $(\mathrm{PR}=1.94,95 \% \mathrm{CI} 1.01-3.71)$, workers who declared themselves to be more alcoholic compared to the others $(\mathrm{PR}=1.94,95 \% \mathrm{CI} 1.38-2.73)$. For the other variables, we found no statistically significant differences.

Table 3 shows the information on hearing handicap according to the occupational and work environment variables. We observed no significant difference for auditory handicap according to the type of construction industry (civil or heavy) and workday duration. However, compared to management professionals and other workers indirectly exposed to noise, plumbers $(\mathrm{PR}=3.20,95 \% \mathrm{CI} 1.38-7.42)$, engineers and architects $(\mathrm{PR}=3.20,95 \% \mathrm{CI}$ $1.21-8.53)$, bricklayers $(\mathrm{PR}=2.16,95 \% \mathrm{CI} 1.18-3.94)$ and surveyors $(\mathrm{PR}=3.50,95 \% \mathrm{CI}$ $1.45-8.46)$ revealed hearing impairment and statistically significant differences. By grouping all workers directly exposed to noise and comparing them to management professionals 
and other workers indirectly exposed, the former group showed higher prevalences of auditory handicap (PR $=2.16,95 \%$ CI 1.75-2.97).

Table 4 shows the prevalence and prevalence ratios of the auditory handicap according to occupational risks and use of hearing protection devices. We observed that the auditory handicap was higher among workers exposed to dust (PR $=1.59 ; 95 \% \mathrm{CI} 1.13$ 2.24), who did not use ear caps ( $\mathrm{PR}=1.39 ; 95 \% \mathrm{CI} 1.01-1.93)$ and who did not use neck flap caps $(\mathrm{PR}=1.45,95 \% \mathrm{CI} 1.03-2.04)$, all with significant statistical differences. Preemployment testing (audiometry) revealed no significant differences between the analyzed groups.

Table 1. Prevalence of auditory handicap in construction workers in Mato Grosso, 2014.

\begin{tabular}{l|c|c}
\hline Variables & $\mathrm{n}$ & $\%$ \\
\hline Auditory handicap & 125 & 14.43 \\
\hline Yes & 741 & 85.57 \\
\hline No & 866 & 100.00 \\
\hline Total &
\end{tabular}

Impact of hearing loss on the emotional aspect ${ }^{*}$

\begin{tabular}{|l|c|c}
\hline Feel embarrassed among strangers & 62 & 49.60 \\
\hline Feel frustrated or dissatisfied when among family & 47 & 37.60 \\
\hline Feel harmed by the auditory problem & 30 & 24.00 \\
\hline Have limitations in individual or social life & 16 & 12.80 \\
\hline Have arguments with family members because of the auditory problem & 12 & 9.60 \\
\hline Impact of hearing loss on the social aspect* & & \\
\hline Difficulty hearing someone whispering & 63 & 50.40 \\
\hline Attend church less & 23 & 18.40 \\
\hline Difficulty when listening to TV or radio & 23 & 18.40 \\
\hline Difficulty when visiting friends & 20 & 16.00 \\
\hline Difficulty when in a restaurant & 15 & 12.00 \\
\hline Grouped impact* & & \\
\hline Complaints regarding the emotional aspect & 167 & 53.70 \\
\hline Complaints regarding the social aspect & 144 & 46.30 \\
\hline Total complaints & 311 & 100.00 \\
\hline
\end{tabular}

*Detailed prevalence of the impact according to the presence of auditory handicap mentioned by the 125 workers in the construction sector. 
In the final model (Table 5), the variables associated with the presence of auditory handicap included: age group 60 years and older; alcoholism; professionals directly exposed to noise and dust; and no use of neck flap cap.

Table 2. Factors associated with auditory handicap according to sociodemographic and lifestyle characteristics of workers in the construction sector in Mato Grosso, 2014.

\section{Variables \\ $\mathrm{n} / \mathrm{N}$ \\ Prevalence (\%) \\ PR \\ $(95 \% \mathrm{Cl})$ \\ p-value}

Demographic data

Sex

\begin{tabular}{l|c|c|c|c|c}
\hline Female & $13 / 84$ & 15.48 & \multirow{2}{*}{0.92} & 1.00 & \multirow{2}{*}{0.775} \\
\cline { 1 - 3 } \cline { 1 - 3 } Male & $112 / 782$ & 14.32 & & $(0.54-1.56)$ & \\
\hline
\end{tabular}

Age group (years)

\begin{tabular}{|c|c|c|c|c|c|}
\hline $17-29$ & $50 / 365$ & 13.70 & & 1.00 & \\
\hline $30-39$ & $34 / 238$ & 14.29 & 1.04 & $(0.69-1.56)$ & 0.838 \\
\hline $40-49$ & $18 / 139$ & 12.95 & 0.94 & $(0.57-1.56)$ & 0.826 \\
\hline $50-59$ & $15 / 94$ & 15.96 & 1.16 & $(0.68-1.98)$ & 0.575 \\
\hline 60 or older & $8 / 30$ & 26.67 & 1.94 & $(1.01-3.71)$ & 0.049 \\
\hline \multicolumn{6}{|l|}{ Grouped education } \\
\hline Illiterate & $2 / 26$ & 7.69 & \multirow{2}{*}{1.90} & 1.00 & \multirow{2}{*}{0.320} \\
\hline Other education levels & $123 / 840$ & 14.64 & & $(0.49-7.28)$ & \\
\hline \multicolumn{6}{|l|}{ Per capta income (BRL) } \\
\hline $76-499$ & $31 / 210$ & 14.76 & & 1.00 & \\
\hline $500-749$ & $21 / 200$ & 10.50 & 0.71 & $(0.42-1.19)$ & 0.195 \\
\hline $750-1.199$ & $37 / 212$ & 17.45 & 1.18 & $(0.76-1.83)$ & 0.452 \\
\hline 1.200 or more & $36 / 244$ & 14.75 & 0.99 & $(0.64-1.55)$ & 0.998 \\
\hline \multicolumn{6}{|l|}{ Lifestyle } \\
\hline \multicolumn{6}{|l|}{ Smoking } \\
\hline No & $101 / 682$ & 14.81 & \multirow{2}{*}{0.88} & 1.00 & \multirow{2}{*}{0.545} \\
\hline Yes & $24 / 184$ & 13.04 & & $(0.58-1.33)$ & \\
\hline \multicolumn{6}{|l|}{ Alcoholism } \\
\hline No & $44 / 445$ & 9.89 & \multirow{2}{*}{1.94} & 1.00 & \multirow{2}{*}{$<0.001$} \\
\hline Yes & $81 / 421$ & 19.24 & & $(1.38-2.73)$ & \\
\hline
\end{tabular}

$\mathrm{PR}=$ prevalence ratio; $95 \% \mathrm{Cl}=95 \%$ confidence interval. 


\section{DISCUSSION}

The prevalence of hearing handicap among construction workers was $14.43 \%(\mathrm{n}=125)$. The interviewees reported several types of emotional and social difficulties resulting from

Table 3. Factors associated with auditory handicap according to the occupational characteristics of workers in the construction sector in Mato Grosso, 2014.

\begin{tabular}{|l|l|l|l|l|l} 
Variables & $\mathrm{n} / \mathrm{N}$ & Prevalence (\%) & $\mathrm{PR}$ & $(95 \% \mathrm{Cl})$ & $\mathrm{p}$-value
\end{tabular}

Type of construction

\begin{tabular}{|c|c|c|c|c|c|}
\hline Civil engineering & $100 / 669$ & 14.95 & \multirow{2}{*}{1.17} & 1.00 & \multirow{2}{*}{0.428} \\
\hline Heavy & $25 / 197$ & 12.69 & & $(0.78-1.77)$ & \\
\hline \multicolumn{6}{|l|}{ Occupation } \\
\hline $\begin{array}{l}\text { Administration professionals } \\
\text { and others* }\end{array}$ & $14 / 157$ & 8.92 & & 1.00 & \\
\hline Amateur professional & $7 / 52$ & 13.46 & 1.50 & $(0.64-3.53)$ & 0.345 \\
\hline Carpenter & $14 / 99$ & 14.14 & 1.58 & $(0.79-3.18)$ & 0.193 \\
\hline Electrician & $4 / 29$ & 13.79 & 1.54 & $(0.54-4.36)$ & 0.415 \\
\hline Plumber & $6 / 21$ & 28.57 & 3.20 & $(1.38-7.42)$ & 0.007 \\
\hline Engineer and architect & $4 / 14$ & 28.57 & 3.20 & $(1.21-8.43)$ & 0.022 \\
\hline $\begin{array}{l}\text { Driver, mechanic and machine } \\
\text { operator }\end{array}$ & $14 / 104$ & 13.46 & 1.50 & $(0.75-3.03)$ & 0.246 \\
\hline Bricklayer & $28 / 145$ & 19.31 & 2.16 & $(1.18-3.94)$ & 0.009 \\
\hline Painter & $4 / 11$ & 36.36 & 4.07 & $(1.61-10.31)$ & 0.004 \\
\hline Doorman and watchman & $3 / 15$ & 20.00 & 2.24 & $(0.72-6.93)$ & 0.170 \\
\hline Bricklayer's mate & $22 / 203$ & 10.84 & 1.21 & $(0.64-2.29)$ & 0.547 \\
\hline Surveyor & $5 / 16$ & 31.25 & 3.50 & $(1.45-8.46)$ & 0.006 \\
\hline \multicolumn{6}{|l|}{ Grouped occupation } \\
\hline $\begin{array}{l}\text { Administration professionals } \\
\text { and others* }\end{array}$ & $14 / 157$ & 8.92 & \multirow{2}{*}{1.75} & 1.00 & \multirow{2}{*}{0.029} \\
\hline $\begin{array}{l}\text { Professionals directly exposed } \\
\text { to noise }\end{array}$ & $111 / 709$ & 15.66 & & $(1.03-2.97)$ & \\
\hline \multicolumn{6}{|l|}{ Working hours } \\
\hline Up to 8 hours & $74 / 548$ & 13.50 & \multirow{2}{*}{1.18} & 1.00 & \multirow{2}{*}{0.306} \\
\hline More than 8 hours & $51 / 318$ & 16.04 & & $(0.85-1.65)$ & \\
\hline
\end{tabular}

${ }^{*}$ Other professionals indirectly exposed to noise; $\mathrm{PR}=$ prevalence ratio; $95 \% \mathrm{Cl}=95 \%$ confidence interval. 
Table 4. Factors associated with auditory handicap according to occupational risks of workers in the construction sector in Mato Grosso, 2014.

\section{Variables}

Type of occupational exposure

Noise

\begin{tabular}{|c|c|c|c|c|c|}
\hline No & $53 / 344$ & 15,41 & \multirow{2}{*}{0,89} & 1,00 & \multirow{2}{*}{0,508} \\
\hline Yes & $72 / 522$ & 13,79 & & $(0,64-1,24)$ & \\
\hline \multicolumn{6}{|c|}{ Vibration machines } \\
\hline No & $99 / 676$ & 14,64 & \multirow{2}{*}{0,93} & 1,00 & \multirow{2}{*}{0,739} \\
\hline Yes & $26 / 190$ & 13,68 & & $(0,62-1,39)$ & \\
\hline \multicolumn{6}{|c|}{ Chemical substances } \\
\hline No & $110 / 746$ & 14,75 & \multirow{2}{*}{0,84} & 1,00 & \multirow{2}{*}{0,516} \\
\hline Yes & $15 / 120$ & 12,50 & & $(0,51-1,40)$ & \\
\hline \multicolumn{6}{|l|}{ Dust } \\
\hline No & $45 / 410$ & 10,98 & \multirow{2}{*}{1,59} & 1,00 & \multirow{2}{*}{0,006} \\
\hline Yes & $80 / 456$ & 17,54 & & $(1,13-2,24)$ & \\
\hline \multicolumn{6}{|c|}{ Tobacco } \\
\hline No & $122 / 839$ & 14,54 & \multirow{2}{*}{0,76} & 1,00 & \multirow{2}{*}{0,617} \\
\hline Yes & $3 / 27$ & 11,11 & & $(0,25-2,24)$ & \\
\hline \multicolumn{6}{|c|}{ Smoke } \\
\hline No & $122 / 823$ & 14,82 & \multirow{2}{*}{0,47} & 1,00 & \multirow{2}{*}{0,153} \\
\hline Yes & $3 / 43$ & 6,98 & & $(0,15-1,41)$ & \\
\hline
\end{tabular}

Pre-employment auditory examination

Audiometry

\begin{tabular}{c|c|c|c|c|c}
\hline Yes & $111 / 766$ & 14,49 & \multirow{1}{*}{0} & 1,00 & \multirow{2}{*}{0,895} \\
\hline No & $14 / 100$ & 14,00 & & $(0,62-1,75)$ & \\
\hline
\end{tabular}

Hearing protection measures

Ear muffs

\begin{tabular}{c|c|c|c|c|c|c}
\hline Yes & $31 / 271$ & 11,44 & \multirow{2}{*}{1,38} & 1,00 & \multirow{2}{*}{0,090} \\
\cline { 1 - 2 } No & $94 / 595$ & 15,80 & & $(0,94-2,01)$ & \\
\hline Ear caps & & & & \\
\hline Yes & $70 / 554$ & 12,64 & 1,39 & 1,00 & \multirow{2}{*}{0,044} \\
\hline No & $55 / 312$ & 17,63 & & $(1,01-1,93)$ & \\
\hline
\end{tabular}


Table 4. Continuation.

\begin{tabular}{|c|c|c|c|c|c|}
\hline Variables & $\mathrm{n} / \mathrm{N}$ & Prevalence (\%) & PR & $(95 \% \mathrm{Cl})$ & $\mathrm{p}$-value \\
\hline \multicolumn{6}{|c|}{ Cap-mount earmuff } \\
\hline Yes & $18 / 156$ & 11,54 & \multirow{2}{*}{1,30} & 1,00 & \multirow{2}{*}{0,255} \\
\hline No & $107 / 710$ & 15,07 & & $(0,81-2,08)$ & \\
\hline \multicolumn{6}{|c|}{ Neck flap cap } \\
\hline Yes & $45 / 390$ & 11,54 & \multirow{2}{*}{1,45} & 1,00 & \multirow{2}{*}{0,028} \\
\hline No & $80 / 476$ & 16,81 & & $(1,03-2,04)$ & \\
\hline
\end{tabular}

$\mathrm{PR}=$ prevalence ratio; $95 \% \mathrm{Cl}=95 \%$ confidence interval.

Table 5. Final Poisson model of variables associated with auditory handicap according to occupational risks of workers in the construction sector in Mato Grosso, 2014.

\begin{tabular}{l|c|c|c}
\hline Variables & PR & $(95 \% \mathrm{Cl})$ & p-value \\
\hline Age group 60 years and older & 2.03 & $(1.09-3.80)$ & 0.026 \\
\hline Alcoholism & 2.00 & $(1.42-2.81)$ & $<0.001$ \\
\hline Professionals directly exposed to noise & 1.79 & $(1.05-3.04)$ & 0.030 \\
\hline Dust & 1.59 & $(1.14-2.23)$ & 0.006 \\
\hline Neck flap cap & 1.52 & $(1.09-2.13)$ & 0.015
\end{tabular}

PR: prevalence ratio; 95\% IC: 95\% confidence interval.

the auditory problem, which include feeling embarrassed among strangers, frustration, difficulty hearing someone whispering and social isolation.

The prevalence of hearing handicap was widely studied among other professionals who are constantly exposed to noise, such as firearm users $(10.60 \%)^{1,3}$ garment workers $(24.10 \%)^{8}$, oven operators $(11.07 \%)^{14}$, foundry workers $(14.47 \%)^{14}$, rolling mill operators $(16.99 \%)^{14}$, mechanical workshop workers $(17.04 \%)^{14}$, fabrication workshop workers $(16.42 \%)^{14}$, and general service workers $(10.37 \%)^{14}$. These prevalences are close to the results obtained in the present study $(14.43 \%)$, since all workers were exposed to high daily levels of sound pressure. However, we were not able to compare the prevalence of hearing handicap found in the present study with other workers in the sector because the literature focus mostly on the conventional audiological data and on noise level and neglect the social and emotional conditions that the auditory sensorial deprivation may cause.

The emotional and social difficulties caused by acquired hearing loss are due, among other causes, to the difficulty workers experience when communicating in their social groups ${ }^{15}$. In this way, when perceiving hearing loss, individuals tends to isolate themselves and communicate less with co-workers ${ }^{2}$. In addition, workers with hearing impairment have more 
difficulty understanding instructions, following routines and meeting obligations, which can increase the risk of work-related accidents ${ }^{8,16}$.

In relation to age, older workers reported higher prevalence of hearing handicap. These findings were compatible with previous studies ${ }^{3,8}$, which revealed that older workers in the construction sector are 2-6 times more likely to have hearing problems than professionals in other activities. This fact is understandable because older individuals tend to be exposed to occupational risk factors for hearing loss for longer periods, and suffer more from the cumulative effect of aging on hearing (presbycusis) ${ }^{7}$.

The present study identified a higher prevalence of hearing loss among workers who declared themselves to be alcoholics. In two systematic reviews ${ }^{17,18}$, alcohol use and abuse were associated with ototoxicity, with damage to the auditory system. However, some authors have found protective effects of low-risk drinking on hearing loss, stating that moderate drinking activates protection mechanisms against disturbances in the cochlear blood flow ${ }^{19,20}$. Still regarding alcohol use, other studies found no significant association between moderate or heavy drinking and hearing loss ${ }^{21,22}$. Considering the high prevalence (50\%) of alcoholism among construction workers found by the present study, it is important to highlight that it is fundamental to prevent alcohol abuse, even though the physiological mechanism that may cause hearing loss has not been clarified.

In the present study, bricklayers, plumbers and professionals directly exposed to occupational hearing hazards had higher prevalences of hearing loss compared to other workers. Leensen et $\mathrm{al}^{1}$. studied medical records of periodic occupational health examinations of construction workers in the Dutch industry and found that bricklayers and plumbers have the highest noise exposure and hearing loss levels. Another study that followed construction workers who underwent periodic occupational hearing screening for a 4-year period also found direct exposure to noise as the main predictor of hearing loss ${ }^{23}$. In an audiometric study with shipbuilding workers in Madrid, Spain, Mur et al. also demonstrated that noise-exposed workers had a prevalence of noise-induced hearing loss 3.1-fold higher than professionals in administrative positions ${ }^{24}$.

It is interesting to note that professional categories supposed to be less exposed to noise and chemical hazards, such as engineers, architects and surveyors, were also associated with high auditory loss rates. One probable explanation is that these professionals, due to their higher level of education, perceive more clearly certain occupational exposure risks, or even their state of health, responding more affirmatively to the HHIE-S. Alves and Rodrigues ${ }^{25}$, in a study on determinants of self-reported health, found that educational level, among other socioeconomic variables, was highly associated with health perception. In addition, occupational safety engineers are professionals belonging to the Specialized Services in Safety Engineering and Occupational Medicine (SESMT) who routinely care about work-related accidents and illnesses ${ }^{26}$.

Hearing loss prevalence was also higher among workers dealing with dust, usually released by cement and substances that make up the mortar, such as sand, gravel and lime. Gerges $^{27}$ observed less effectiveness of hearing protective devices by the presence of dust 
in confined spaces. Some dust found in the work environment, when penetrating the ear either by simply obstructing the ear canal or by the degree of ototoxicity of some chemicals in its composition - can cause hearing loss, also influencing the worker to refer a higher hearing loss rate ${ }^{28}$.

Regarding the use of personal protective equipment (PPE), workers who did not wear neck flap caps and ear muffs revealed higher prevalence of hearing loss. Despite the need for hearing protection, elevated temperatures in the study sites and discomfort cause workers to use PPE improperly. In addition, there was no reference to hearing conservation programs at any construction site where the study was conducted. In view of the results of the present study, we suggest that these programs be implemented in order to identify and evaluate the risks and auditory exams, promote the use of individual and collective protection and establish training programs to prevent hearing loss among workers ${ }^{29,30}$.

Regarding hearing tests, we found no statistically significant differences in the high rates of hearing loss among workers who underwent pre-employment audiometry and the others. However, some workers declared that they had never undergone any type of pre-employment hearing test. This situation is worrying, since studies show that the work environment in the construction sector presents high levels of sound pressure and other harmful agents to the auditory system, configuring an important public health problem ${ }^{2-4}$.

The results of the present study point to the need for hearing monitoring through the investigation of auditory handicap among construction workers, as established by the Occupational Health Medical Control Program (PCMSO) part of the Brazilian Consolidation of Labor Laws $(\mathrm{CLT})^{31}$. Thus, it is important to reinforce auditory handicap research with routine audiological assessments related to the work environment in order to understand the real dimension of the auditory problem and its consequences to the worker's quality of life, as well as to support specific prevention and promotion measures aimed at workers' auditory health.

Some limitations of this study should be considered. We were not able to carry out audiometric tests due to difficulties in the application of an epidemiological inquiry with collection of various other information on exposure and work-related diseases. Thus, we opted to apply the self-reported auditory handicap questionnaire as proxy information for hearing loss. This instrument is recommended for hearing screenings, as a complement to traditional audiological assessments and even as validation of the hearing protection process ${ }^{7,8}$.

It is important to point out that instruments for direct hearing loss assessment, such as audiometry screening, can not definitively express the real emotional and social impact on daily life ${ }^{32}$, which makes the assessment of auditory handicap a differential in this study.

As for the study design, cross-sectional surveys determine both exposure factors and outcome (auditory handicap), making it difficult to establish a temporal relationship between events. Thus, parsimony is important in the interpretation of casual effects. The non-probability sampling technique used in the present study is a limitation, which may result in poor 
external validity. Another limitation refers to the fact that pre-employment medical tests are performed when workers enter the construction industry, selecting only the healthiest individuals to work in the companies. This selection may lead to the occurrence of a "healthy worker effect", whereby workers with established hearing loss are rejected after the medical tests $^{33,34}$. Also, we should not exclude a possible memory bias because the questionnaire is based on participants' recall, in which the most exposed workers may have better remembered the activities with risks of hearing loss.

\section{CONCLUSION}

The study showed a presence of self-reported hearing handicap, with emotional and social complaints among workers in the construction sector. Due to the presence of auditory alterations, workers reported having undergone various psychosocial problems, hearing difficulties and even social isolation.

The assessment of auditory handicap was important for the monitoring of worker's hearing health. It is necessary to effectively implement public policies for the promotion and prevention of hearing loss induced by high sound pressure levels and the conservation of the auditory health of workers in the construction sector.

\section{REFERENCES}

1. Leensen MC, Van Duivenbooden JC, Dreschler WA. A retrospective analysis of noise-induced hearing loss in the Dutch construction industry. Int Arch Occup Environ Health 2011 Jun; 84(5): 577-90.

2. Deacon C, Smallwood J, Haupt T. The health and wellbeing of older construction workers. International Congress Serie 2005; 1280: 172-7.

3. Ringen K, Dement J, Welch L, Dong XS, Bingham E, Quinn PS. Risks of a lifetime in construction. Part II: Chronic occupational diseases. Am J Ind Med 2014 Nov; 57(11): 1235-45.

4. Empresa de Tecnologia e Informações da Previdência Social. [Internet]. Brasília: Base de dados Históricos de Acidentes de Trabalho [s.d.] [cited on 2014 Nov 2014]. Available from: http://www3.dataprev.gov. br/AEAT/greg/reg04/reg04.PHP

5. Cruz MS, Oliveira LR, Carandina L, Lima MCP, César CLG, Barros MBA, et al. Prevalência de deficiência auditiva referida e causas atribuídas: um estudo de base populacional. Cad Saúde Pública 2009 May; 25(5): 1123-31

6. Organização Mundial da Saúde. Rumo a uma Linguagem Comum para Funcionalidade, Incapacidade e Saúde CIF [Internet]. Genebra: WHO; 2002 [cited on 2014 Nov 9]. Available from: http: / / www.paho.org/ bracolab $/$ index.php?option $=$ com_docman $\&$ task $=$ doc details\&gid $=105$ \&Itemid $=310$

7. Menegotto IH, Soldera LCH, Anderle P, Anhaia TC. Correlation between hearing loss and the results of the following questionnaires: Hearing Handicap Inventory for the Adults - Screening Version HHIA-S e Hearing Handicap Inventory for the Elderly - Screening Version - HHIE-S. Arq Int Otorrinolaringol 2011; 15(3): 319-26.

8. Alves AS, Fiorini AC. A autopercepção do handicap auditivo em trabalhadores de uma indústria têxtil. Distúrb comum 2012 Dec; 24(3): 337-49.

9. Luiz RR, Magnanini MMF. A lógica da determinação do tamanho da amostra em investigações epidemiológicas. Cad Saúde Colet 2000; 8(2): 9-28.

10. Ventry IM, Weinstein BE. Audiometric correlates of the hearing handicap inventory for the elderly. J Speech Hear Disord 1983; 48: 379-84.

11. Wieselberg MB. A auto-avaliação do handicap em idosos portadores de deficiência auditiva: o uso do HHIE [dissertação]. São Paulo: Pontifícia Universidade Católica de São Paulo; 1997. 
12. Carvalho RM, Iório MCM. Eficácia da aplicação do questionário de handicap em idosos deficientes auditivos. Distúrb Comun 2007; 19(2): 163-72.

13. Stewart M, Pankiw R, Lehman ME, Simpson TH. Hearing loss and hearing handicap in users of recreational firearms. J Am Acad Audiol 2002; 13(3): 160-8.

14. Gomes J, Lloyd O, Norman N. The health of the workers in a rapidly developing country: effects of occupational exposure to noise and heat. Occup Med 2002; 52(3): 121-8.

15. Francelin MAS, Motti TFG, Morita I. As Implicações Sociais da Deficiência Auditiva Adquirida em Adultos. Saúde Soc 2010; 19(1): 180-92.

16. Lima II, Aiello CP, Ferrari DV. Correlações audiométricas do questionário de handicap auditivo para adultos. Rev CEFAC 2011 Jun; 13(3): 496-503.

17. Samokhvalov AV, Popova S, Room R, Ramonas M, Rehm J. Disability associated with alcohol abuse and dependence. Alcohol Clin Exp Res 2010 Nov; 34(11): 1871-8.

18. Bellé M, Sartori SA, Rossi AG. Alcoholism: effects on the cochleo-vestibular apparatus. Braz J Otorhinolaryngol 2007; 73:110-6.

19. Fransen E, Topsakal V, Hendrickx JJ, Van Laer L, Huyghe JR, Van Eyken E, et al. Occupational noise, smoking, and a high body mass index are risk factors for age-related hearing impairment and moderate alcohol consumption is protective: a European population-based multicenter study. J Assoc Res Otolaryngol 2008; 9: 264-76.

20. Popelka MM, Cruickshanks KJ, Wiley TL, Tweed TS, Klein BE, Klein R, et al. Moderate alcohol consumption and hearing loss: a protective effect. J Am Geriatr Soc 2000; 48: 1273-8.

21. Curhan SG, Eavey R, Shargorodsky J, Curhan GC. Analgesic Use and the Risk of Hearing Loss in Men. Am J Med 2010; 123: 231-7.

22. Curhan SG, Eavey R, Shargorodsky J, Curhan GC. Prospective Study of Alcohol Use and Hearing Loss in Men. Ear Hear 2011; 32(1): 46-52.

23. Leensen MC, Dreschler WA. Longitudinal changes in hearing threshold levels of noise-exposed construction workers. Int Arch Occup Environ Health 2015 Jan; 88(1): 45-60.
24. Mur PG, Bermúdez BP, Monroy AM. Pérdidas auditivas relacionadas con la exposición a ruido en trabajadores de la construcción. Med Segur Trab 2008 Dec; 54(213): 33-40.

25. Alves L, Rodrigues RN. Determinantes da autopercepção de saúde entre idosos do Município de São Paulo, Brasil. Rev Panam Salud Publica 2005; 17(5 / 6): 333-41.

26. Teixeira MC. A invisibilidade das doenças e acidentes do trabalho na sociedade atual. Rev Dir Sanitário 2012; 13(1): 102-31.

27. Gerges SNY. Critérios importantes. Rev Prot 2007; 183.

28. Liao EC, Chang KC. Mites in the External Auditory Canal. N Engl J Med 2012 Oct; 367: e19.

29. Comitê Nacional de Ruído e Conservação Auditiva. Boletim n ${ }^{\circ} 6$ [Internet]. Arq Fund Otorrinolaringol. 2000 [cited on 2000 Apr/June]; 4(2). Available from: http:/ / arquivosdeorl.org.br/conteudo/acervo_port. asp?id $=125$

30. Oliveira WTGH, Andrade WTL, Teixeira CF, Lima MLLT. Audição de Trabalhadores Antes e Após o Programa de Conservação Auditiva. Rev Bras Ciên Saúde 2012; 16(4): 517-24.

31. Brasília (Distrito Federal). Portaria n ${ }^{\circ} 24$, de 29 de dezembro de 1994. Aprova o Programa de Controle Médico de Saúde Ocupacional. Diário Oficial da União. 30 dez 1994.

32. Rosis ACA, Souza MRF, Iório MCM. Questionário Hearing Handicap Inventory for the Elderly Screening version (HHIE-S): estudo da sensibilidade e especificidade. Rev Soc Bras Fonoaudiol 2009; 14(3): 339-45.

33. Hardman CM, Barros SSH, Oliveira ESA, Nahas MV, Barros MVG. Inatividade nos deslocamentos para o trabalho e fatores associados em industriários. Saúde Soc 2013 Sep; 22(3): 760-72.

34. Graudenz GS. Indicadores infecciosos e inflamatórios entre trabalhadores da limpeza urbana em São Paulo. Rev Bras Saúde Ocup 2009 Dec; 34(120): 106-14.

Received on: 07/14/2016

Final version presented on: 04/29/2017

Accepted on: 05/18/2017 